(c) 2018 Dzhurylo. This article is distributed under the terms of CC Attribution-ShareAlike 4.0 International

UDC: 37.014 .3

\title{
EDUCATIONAL REFORM IN THE EU COUNTRIES AND UKRAINE: HISTORICAL BACKGROUND, CURRENT ISSUES AND FUTURE PROSPECTS
}

\author{
Alina Dzhurylo \\ Ph.D. in Education, \\ Institute of Pedagogy, National Academy of Educational Sciences of Ukraine, Kyiv, Ukraine \\ ORCID: 0000-0002-5129-6724,e-mail:dzhurylo.ap@gmail.com
}

The article deals with the historical background, current issues and future challenges of educational reform in the countries of the European Union. It has been shown that the educational policy of the last century was aimed at increasing the length of compulsory secondary education to 18 years, early engagement of children in primary education and increasing its duration. The issue of decentralization as an educational trend in all European countries since the 1920s has been raised.

The author analyses educational policy of the EU at the present stage, which is aimed at forming in European schools the necessary skills for their successful selfrealization in society, including digital skills for future jobs, and the overcoming of gender differences in mathematics and sciences starting from school level. In the EU's current educational policy the following priority areas can be identified: all pupils should gain the competences they need; every pupil should benefit from high-quality learning, including migrant children; early childhood education and care should be more widely available, support for learners with special needs must be improved within mainstream schooling and reduction of early school leaving; teachers, school leaders, and educators should receive more support, including career-long professional learning opportunities; quality assurance should be further developed to ensure a more effective, equitable and efficient governance of school education and to facilitate learner mobility. The issue concerning creating a European education area by 2025 is revealed.

The European vector of Ukraine's development has been analysed, which has been considered as a priority since the proclamation of independence and confirmation of the Association Agreement between Ukraine and the European Union.

Key words: educational reform, educational policy, global transformations, the European Commission, the European Union, the EU countries, Ukraine.

У статті розглянуто історичне тло, сучасний стан та майбутні Виклики осъітнъой реформи у крайнах ЄВропейсъкого Союзу. ВяВлено, шео освітня політика минулого століття була спрямована на збільшення тривалості обовязкової середнъої освіти до 18 років, ранне залучення дітей до початкової освіти та збільшення їі тривалості. Піднято питання децентралізації як освітнъого тренду в усіх ЄВропейсъких крайнах з 1920 рр. Проаналізовано освітню політику ЄС на 
сучасному етапі, яка спрямована на формування у європейсъких школіряв необхідних навичок для їх успішної саморееллізиї у суспільстві, у тому числі $i$ иифрових навичок для професій майбутнъого; подолення гендерної розбіжності $b$ математиці й технічних науках ще зі школи. В сучасній освітній політиці СС можна виділити наступні ключові напрями: всі учні мають отримати належні ім компетениї; кожен ученъ повинен отримати високоякісне навчання, включаючи дітей-мігрантів, дошкільна освіти має стати більи доступною, система підтримки для учніВ з особливими потребами повинна бути Вдосконалена у рамках загальноосвітнъого навчання; ріВень школярів, що рано залишають школу має бути скорочено; вчителі, керівники шкіл та педагоги повинні отримувати необхідну підтримку, включаючи можливості для профресійного навчання; подальшого розвитку має набувати система забезпечення якості, щоб забезпечити більи ефективне, справедливе та ефективне управління икільню освітою; сприяти освітній мобільності. Розкрито питання створення Європейсъкого освітнъого простору до 2025 року.

Проаналізовано європейський Вектор розВитку Украӥни, що розглядається як пріоритетнии з часу проголочення незалежності та підтверджений підписання Угоди про асоціацію між Украйною та Європейсъким Союзом.

Киючові слова: осъітня реформа, осъітня політика, глобальні перетворення, Європейсъка комісія, Європейсъкий Союз, крайни ЄС, Украйна.

\section{Introduction}

Global transformations of the modern world in the area of political, economic, social and cultural fields change the demands for professional and civic characteristics of the individual. The challenges of social progress lead the world countries to implementation of major changes in education. Transformation is taking place in the context of understanding such dilemmas as the need, on the one hand, to provide the economy and labour markets with highly professional workers, and, on the other hand, to build social harmony, interpenetration of cultures and strengthening of national identity.

The objective of the paper is to analyse the historical background, current issues and future prospects of educational reform in the EU countries for the formation of educational policy in Ukraine as an associate member.

The issues of educational policy in both Ukraine and European countries are analysed in the works of such Ukrainian scientists such as V. Andriuschenko, N. Avshenuk, A. Demyanchuk, V. Galperina, I. Ivanyuk, V. Kremen, O. Lokshuna, V. Lugovyi, O. Matvienko, V. Ognevyuk, O. Ovcharuk, L. Pukhovska, A.Sbrueva, S. Sysoyeva, O. Zabolotna, V. Zhuravskyi and others. The Europe 2020 strategy acknowledges that a fundamental transformation of education and training is needed to address the new skills and competences that will be required if Europe is to remain competitive, overcome the current economic crisis and grasp new opportunities. Innovating in education and training is a key priority in several flagship initiatives of the Europe 2020 strategy, in particular the Agenda for New Skills and Jobs, Youth on the Move, the Digital Agenda, and the Innovation Union Agenda. Consequently, one of the five targets for measuring the success of the Europe 2020 strategy is the modernization of European Education and Training systems with the goals of reducing early school leaving and increasing tertiary education attainment.

Historical Background

European systems of public schooling date back from the $18^{\text {th }}$ century. Elementary education systems at the dawn of the $20^{\text {th }}$ century were therefore all ruled by laws dating from the $19^{\text {th }}$ century. Hence, the population attending elementary schools at the beginning of the $20^{\text {th }}$ century beneficiated from institutionalised systems inherited from the end of the 
19th century. During the 20th century, the reforms undertaken by the majority of the countries included the extension of compulsory schooling and the implementation of measures to ensure that all pupils would obtain a certificate of basic education, including new learner-centred methods and new examination schemes. In some countries, these efforts went as far as the institutionalization of compulsory education up to the age of 18 . Thus, the national structure and content of primary education programmes are directly linked to the evolution of compulsory education. Today, the primary education level begins between 5 and 7 years of age, is compulsory in all countries and generally lasts from 4 to 6 years (OECD, 2002) [4, c. 13 - 14].

Apart from the quantitative improvement of education attainment, achieved through the implementation of compulsory basic education, in the $20^{\text {th }}$ century it was also the emergence of a qualitative trend, especially from the second half of the century. A basic education of 'quality' became an essential pre-requisite for the development of a knowledge society. This quality dimension materialized through the adoption of new teacher recruitment policies, implying new teacher training structures and new monetary teaching incentives (e.g. higher teacher salaries). From the pupils' perspective, the development of higher quality standards passed through the expansion of language acquisition schemes and the integration of special educational needs programmes into the main (or "regular") classes [4, c. $13-14]$.

Decentralization is the most common educational reform in the EU in both federal and unitary states. Decentralization is defined as the transfer of decision-making authority closer to the consumer or beneficiary. Among the first countries launch the decentralization of education by law is the Netherlands, where since a law of 1917, all schools, both public and private, have been governed by a legally organised competent authority which is responsible for implementing legislation and regulations in schools. Italy was second to initiate the process of decentralization of school authority in the 1970s. In 1991 the first national experimentation of full school autonomy was conducted. In the 1980s, the Netherlands and Italy were joined by several countries, among which Greece, France, Sweden and Belgium. In the 1990s, the Czech Republic and Austria launched their own decentralization reforms. Finally, in Portugal, it was only in 2001, with the Statutory Order 6 of 18 January, that basic schools got allowed to establish certain specific curricula areas and draw up precise timetables for the subjects included in their study plans [4, c. 88 - 92].

\section{Current Issues}

Nowadays the European Commission works with EU countries to develop their school education systems. While each country is responsible for the organisation and content of its education and training systems, there are advantages in working together on issues of shared concern. The European Commission supports national efforts in two main ways: it gathers and shares information and analysis and encourages the exchange of good policy practices through the ET2020 Working Groups. In 2016-2018, the Working Group on Schools has a broad mandate to work on the governance of school education systems in order to promote higher quality through sustainable innovation and inclusion. Through the Erasmus programme, the Commission contributes millions of euros each year to European cooperation projects that promote school exchanges [1].

Despite understanding pivotal role of schools in life-long learning, all the EU countries are facing several key challenges. There are weaknesses in competence development at school education level. The latest results of the OECD PISA survey show that one in five pupils have serious difficulties in developing sufficient reading, mathematics and science skills. School education does not always play in full its role to promote equity and social fairness. PISA data reveal that gender gaps in mathematics and science are narrowing; however gender stereotypes still lead to differences in engagement 
in science and ICT and need more attention. The pace of technological and digital change is having a profound effect on European economies and societies - schools need to respond better to this new reality. Many of today's school children will later work in job types that do not yet exist. Already $90 \%$ of all current jobs require at least some level of digital skills [2].

Education ministers from EU countries have identified the following priority areas: - All pupils should gain the competences they need. This is realising through modernising curricula, learning materials and pupil assessment;

- Every pupil should benefit from high-quality learning, including migrant children;

- Early childhood education and care should be more widely available, support for learners with special needs must be improved within mainstream schooling and early school leaving reduced;

- Teachers, school leaders, and educators should receive more support, including career-long professional learning opportunities;

- Quality assurance should be further developed to ensure a more effective, equitable and efficient governance of school education and to facilitate learner mobility [1].

Future Prospects

On 17 November 2017 on the meeting in Gothenburg (Sweden) the EU leaders discussed the creation of a European Education Area by 2025. The European Commission considers it as the shared interest of all Member States to harness the full potential of education and culture as drivers for job creation, economic growth and social fairness as well as a means to experience European identity in all its diversity [6].

A European Area of Education should include [6]:

- Making mobility a reality for all: by building on the positive experiences of the Erasmus+ programme and the European Solidarity Corps and expanding participation in them as well as by creating an EU Student Card to offer a new userfriendly way to store information on a person's academic records;

- The mutual recognition of diplomas: by initiating a new "Sorbonne process", building on the "Bologna process", to prepare the ground for the mutual recognition of higher education and school leaving diplomas;

- Greater cooperation on curricula development: by making recommendations to ensure education systems impart all the knowledge, skills and competences that are deemed essential in today's world;

- Improving language learning: by setting a new benchmark for all young Europeans finishing upper secondary education to have a good knowledge of two languages in addition to their mother tongue(s) by 2025;

- Promoting lifelong learning: by seeking convergence and increasing the share of people engaging in learning throughout their lives with the aim of reaching $25 \%$ by 2025;

- Mainstreaming innovation and digital skills in education: by promoting innovative and digital training and preparing a new Digital Education Action Plan;

- Supporting teachers: by multiplying the number of teachers participating in the Erasmus+ programme and eTwinning network and offering policy guidance on the professional development of teachers and school leaders;

- Creating a network of European universities so that world-class European universities can work together across borders, as well supporting the establishment of a School of European and Transnational Governance;

- Investing in education: by using the European Semester to support structural reforms to improve education policy, using EU funding and EU investment 
instruments to fund education and setting a benchmark for Member States to invest $5 \%$ of GDP in education.

- Preserving cultural heritage and fostering a sense of a European identity and culture: by developing - using the momentum of the 2018 European Year of Cultural Heritage - a European Agenda for Culture and preparing a Council Recommendation on common values, inclusive education and the European dimension of teaching.

- Strengthening the European dimension of Euronews, which was created in 1993 by a number of European public broadcasters, with the ambition of having a European channel offering access to independent, high quality information with a panEuropean perspective [6].

Over the past decade, the European Union has also developed a series of 'soft policy' tools to help Member States in the design of national education policies. Since 2000, Member States have been cooperating under the "Framework for European cooperation in education and training" which set common objectives and benchmarks. In 2010, the EU set itself two education targets under the Europe 2020 Strategy where real progress has already been attained. Early school leaving was reduced from $13.9 \%$ in 2010 to $10.7 \%$ in 2016, with the target to reach $10 \%$ by 2020 . And tertiary educational attainment was up to $39.1 \%$ in 2016 from $34 \%$ in 2010 , with the target of $40 \%$ by 2020 [6].

The Commission believes it is time now to build on these foundations and greatly step up European ambition. To steer this reform and to stimulate discussion as Europe looks to its future, Jean-Claude Juncker, the president of the European Commission, proposed in his State of the Union Address of 13 September 2017 a "Roadmap for a More United, Stronger and More Democratic Union" [3].

The Europe's leaders committed to creating a "Union where young people receive the best education and training and can study and find jobs across the continent". The Commission believes that education and culture can be an important part of the solution in tackling the challenges of an ageing workforce, continued digitalisation, future needs for skills, the need to promote critical thinking and media literacy in an era where "alternative facts" and disinformation can proliferate online, as well as the need to foster a greater sense of belonging in face of populism and xenophobia [6].

The European vector of development of Ukraine has been considered as a priority since the proclamation of independence in 1991. The Association Agreement between Ukraine and the European Union (2014) has finally confirmed the European direction of Ukraine's development. The agreement recognizes that Ukraine as a European country shares the common history and values with the EU member states; notes the importance for Ukraine to be attached to its European identity; stresses the strong public support of the European choice of the country; confirms that the EU recognizes the European aspirations of Ukraine and welcomes its European choice (2014) [5].

Chapter 23 of the Association Agreement entitled "Education, Training, and Youth" points to the need to intensify cooperation in the field of education, which involves harmonizing key parameters of Ukrainian education with the European, intensifying its integration into the European educational space: reforming and modernising the education systems; promoting convergence in the field of higher education deriving from the Bologna process; enhancing the quality and relevance of education; stepping up cooperation between education institutions; building up the capacity of education institutions; increasing student and teacher mobility: attention will be paid to cooperation in the field of education with a view to facilitating access to education [5].

The European vector of Ukraine's policy in the conditions of independence contributed to the European orientation of Ukrainian education. All legislative and strategic 
documents defining the development of Ukrainian education declare the integration of Ukrainian education in the European education area [5].

For this purpose Ukrainian school education is undergoing constant transformation started with decommunisation, training the young generation in the spirit of national and European values immediately after independence in 1991. Europeanization of education in Ukraine has increased after the signing of the Association Agreement between Ukraine and the EU (2014). Therefore, all the educational challenges facing the EU countries today touch on Ukraine as well [5].

Europeanization has a direct and indirect influence on the development of education in Ukraine, which manifests itself in the format of harmonization with the EU countries of key indicators that determine the directions and essence of educational development. Large-scale eurointegration reforms in Ukraine at the level of school education cover the transformation of both the structure and the content of education.

\section{Conclusions}

It should be noted that in strategic documents which defined the development of national education in Ukraine, last one is mentioned as an important resource for improving publics well-being, an instrument for ensuring national interests, strengthening the competitiveness of the Ukrainian state at the international level, and the quality of education is defined as a national priority and a prerequisite for national security.

To summarize, the essence of both the reform of the structure and the content of secondary education in Ukraine is synchronized with the reforms in the EU, although reforms in Ukraine are accompanied by challenges of political and economic nature, characterized by lagging time in comparison with the EU countries. It should be noted that the strategic reference point for reforms in the conditions of European integration of Ukraine remains the entry into the European educational space, harmonization with the standards defining the development of education in the EU.

\section{References:}

1. European Commission. About School Policy. Retrieved from https://ec.europa.eu/education/policies/school/about-school-policy_en

2. European Commission (2017). Communication from the Commission to the European Parliament, the Council, the European. School Development and Excellent Teaching for a Great Start in Life. Brussels. Retrieved from https://eur-lex.europa.eu/legalcontent/EN/TXT/PDF/? uri $=$ CELEX:52017DC0248Efrom $=E N$

3. European Commission (2017). Roadmap for a More United, Stronger and More Democratic Union. Retrieved from https://ec.europa.eu/commission/sites/beta-political/files/roadmap-soteufactsheet_en.pdf

4. Garrouste, Christelle (2010). 100 Years of Educational Reforms in Europe: a Contextual Database, Luxembourg: European Commission, Joint Research Centre. Retrieved from http://publications.jrc.ec.europa.eu/repository/bitstream//RC57357/reqno_jrc57357.pdf

5. Official EN Journal of the European Union (2014). Association Agreement between the European Union and its Member States, of the one part, and Ukraine, of the other part. Retrieved from https://trade.ec.europa.eu/doclib/docs/2016/november/tradoc_155103.pdf

6. Stefancik, Stefan (2017, November 14). Future of Europe: Towards a European Education Area by 2025. Retrieved from http://www.vitainternational.media/en/article/2017/11/14/future-ofeurope-towards-a-european-education-area-by-2025/713/ 